Language

Ten

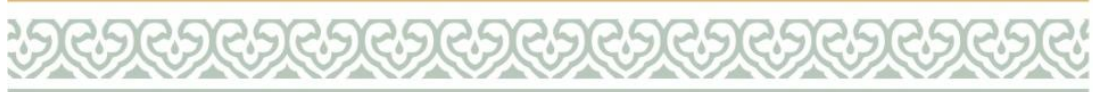

Язык

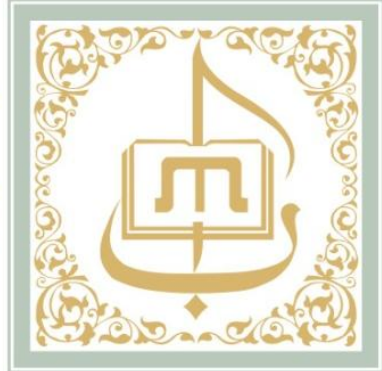

\title{
LEXICAL UNITS REFLECTING AGE FEATURES IN THE TATAR AND AZERBAIJANI LANGUAGES
}

\author{
Mahira Nagievna Guseynova, \\ Azerbaijan State Pedagogical University, \\ 68 U. Gadzhibeyli Str., Baku, Azerbaijan, \\ mahire.huseynova@adpu.edu.az.
}

Firuza Ramzilevna Sibgaeva, Kazan Federal University, 18 Kremlevskaya Str., Kazan, 420008, Russian Federation, FiruzaRS@mail.ru.

\begin{abstract}
In recent years, linguistic phenomena has been studied in connection with a person's worldview, thinking and spiritual world. In fact, the concepts of the human language cannot be represented separately from each other, most of each language is made up of lexical units and concepts associated with a person. Among them is the vocabulary that reflects age characteristics of a person. A person's physical and, in most cases, mental strength, skills, degree of participation in public life are directly related to one's age.

This article studies lexical units reflecting age features of a person, they determine not only age differences, but also people's characters and their internal state of mind.
\end{abstract}

Key words: lexical units reflecting age features, Tatar language, Azerbaijani language, linguistic picture of the world, public term, age feature, period.

The word names a phenomenon, or an object in the surrounding reality and through this property it directly conveys the systemic nature of real life. Lexis, reflecting age characteristics, existed in very ancient times; therefore, the study of its meanings and associated customs and traditions makes it possible to represent an ancient life, to clarify various events in the past.
In the past few decades, there is a growing tendency to study linguistic phenomena in conjunction with a person's worldview, spiritual world and outlook. Indeed, a person and linguistic concepts cannot exist separately, most of each language is made up of lexical units, associated with a person. Among them is the vocabulary that reflects age characteristics of a person. This is quite understandable. The physical and, in most 
cases, the spiritual strength of people, their skills and the level of participation in public life are directly related to their age characteristics.

Among the scientific research, devoted to the study of lexis, expressing age characteristics in the Tatar and Azerbaijani languages, the works by the following researchers can be noted: A. Bekmuratova [1978], E. Aybazova [1981], D. Shikhmurzaev [1985], Kh. Yusupov [1959] and others; in individual dialects and accents, lexical units, expressing age characteristics, are studied by M. Abakarova, N. Hajiakhmedov [1985], their works are devoted to the names of kinship relations; in the works of S. Mirzhanova [1973] lexis, expressing age characteristics, is studied.

In this area, we find the etymological dictionaries compiled by E. V. Sevortyan [1974, 1978, 1980, 1986]. They contain and analyze a great deal of factual material on the ancient and modern Turkic languages and consider general theoretical issues concerning the emergence of the vocabulary, expressing age characteristics, its semantic and functional features of the development.

Age is an important component of a person's life and consciousness, being one of the universal categories. Every moment of human life always arouses interest in a person. The problem of time in linguistics is reflected in the ontological and linguocultural aspects in the works of $E$. Yakovleva [Yakovleva, 1994]. Consequently, scientific interest in lexis, expressing age-specific features as a connection between a person and time, is returning. Scientists study vocabulary, expressing age features, in different ways. R. Khashimov, G. Putyagin, V. Gak and L. Kostin researched this kind of vocabulary in the 1970s and R. Khashimov was one of the first to study this lexis [Hashimov, 1973, p. 21].

Age-specific vocabulary holds a special place in numerous bilingual dictionaries of the $19^{\text {th }}$ century.

A. Yusupova's work "Bilingual Lexicography of the Tatar Language of the $19^{\text {th }}$ Century" [2008] provides a detailed and most comprehensive description of this vocabulary. The author rightfully notes that the study of the vocabulary in these dictionaries is very important for Lexical Studies of the Tatar language in the historical aspect.

The desire to study the lexical fund of the language comprehensively and fully encourages diverse scientific research, opening up different ways of collecting lexical data. Recently, a voluminous monograph by D. Ramazanova "Tatar telenda keshega bailaneshle lexicon" [In Tatar: Lexis Related to a Person] has been published [Ramazanova, 2013, p. 8].

The article uses various methods to analyze the factual material. The collected data are classified based on the observation and description methods, the main methods in linguistics. In addition, in the analysis of lexical units, we use comparativehistorical, descriptive methods, methods of typological, semantic analysis and the method of anthropocentric analysis.

In the center of lexical units, expressing age features in the Tatar language, is the word "yash" (year, age). In the "Explanatory Dictionary of the Tatar Language" its two meanings are indicated: 1) one year of the life of a person or some animals; 2) the lifetime of a person, animal, plant [Explanatory Dictionary of the Tatar Language, 2005, p. 739].

Depending on the chronological age of a person, he/she is called differently. Among the Tatars, a newborn baby is called babi, saby, narasy and kukrak balasy. The meaning of the word babi, recorded in the dictionary, is "newborn, baby" [Explanatory Dictionary of the Tatar Language, 2005, p. 101]. The dictionary emphasizes the independent status of the lexeme imchak (breast) [Explanatory Dictionary of the Tatar Language, 2005, p. 185].

Saby is defined as 1) very small (about children); the one who thinks superficially, without delving into the essence of the problem; small; 2) like small ones (face, appearance, etc.); 3) the years of infancy (period, time, etc.) [Explanatory Dictionary of the Tatar Language, 2005, p. 456].

The definition of the word nani is given as "a little child" [Explanatory Dictionary of the Tatar Language, 2005, p. 390].

As a word for addressing children, the lexeme bapkam is given, which is also included into this group. The third meaning of the word bapkam is given in the dictionary as: "The way adults address the young ones, especially the little ones" [Explanatory Dictionary of the Tatar Language, 2005, p. 103].

In the territorial dialects of the Tatar language, various words are used to express the meaning of bala (child). For example, in some dialects a newborn, a young child is usually called peti. In the dictionary, L. Makhmutova writes: peti is small [Big Dialectological Dictionary of the Tatar Language, 2009, p. 528]. Also, the dictionary contains the words miras bala, used in the dialects of kargaly, barange in relation to children whose 
father died [Big Dialectological Dictionary of the Tatar Language, 2009, p. 479].

Women who helped with childbirth, advised, consoled, performed the first hygiene procedures, were called kendek abise. Drawing attention to various interpretations of the word, F. Bayazitova gives the following lexical units as an example: kendek abi, kendekay, olan abise, babai abise, tuti abi, abi tata, abi anka, inalek kortkayak, mamay, avyl abise and others [Bayazitova, 2014, p. 35]. Moreover, the events related to the birth of a child are differently named: babi mae - in the Kazan and Mishar dialects; babi tue, babi botkasy - in the dialects of the mountain side; baabi chae - in the Kasimov and Sergach dialects.

In the Tatar language, the period of "childhood" is reflected in a fairly large number of lexemes. On the basis of the lexeme bala, which is central in this group, many new words have been formed: balasytu, balalanu, balalau, balaga uzu, bala tosheru, balachak, balasyz, bala-chaga. As you can see, they are formed by the method of suffixation and the addition of the suffix to the stem. What is noteworthy: the compound noun balachaga (children) is formed by joining the word bala with its dialect version of chaga. In some accents of the Mishar dialect, the word chaga expresses a meaning close to the word bala, therefore, it has the meaning of "the word used in relation to the young ones of such small animals as dogs, cats, pigs, and rabbits" [Big Dialectological Dictionary of the Tatar Language, 2014, p. 723].

In the Azerbaijani language, the lexical units bəbə, körpə, çağa are used to convey the meaning of a child, a baby. The word cunqus, which has passed from the active to passive vocabulary of the Azerbaijani language, exists only in some dialects. The lexical unit körpə functions as an active lexical unit. It conveys the meanings of an infant, a small child, a baby [https://translate.academic.ru]: körpo nəfasi (the baby's breath), körpəni amizdirmək (to breastfeed a baby), körpəni sakit etmək (to soothe the baby), körpəni qucağına götürmək (almaq) (to take the baby in one's arms), körpani bağrina basmaq (to hug the baby to the chest), körpani döş⿰丿丶 ayırmaq (to wean the baby), körpəyə ad qoymaq (to give a name to the baby), körpəyə Layla çalmaq (put the baby to bed).

Also, the word körpa means young. For example, Sən hən hən çox körpasən (you are still too young to be naughty), insanlarl mühakimə etmək üçün siz halək körpasiniz (you are too young to judge people).
Adults refer to younger ones: oglum (son), qızım (daughter).

When talking about a child, the Tatar and Azerbaijani peoples mean the period from infancy to twelve years of age. The lexemes, given in the dictionaries, on the one hand, emphasize that the child is inexperienced and naive (kochek, boryn asty kipmagan, manka), on the other hand, show the main social role of children - their connection with learning and upbringing (ukuchy, shakert, talip). The analysis notes a great role the gender plays in distinguishing children (a girl, a boy). The gender division in both languages is associated with changes that are characteristic only of these people. Leaving childhood behind, the child enters adolescence.

The adolescent period is "from childhood to adolescence," and the adolescent is "a child from 12 to 16-17 years old" [Explanatory Dictionary of the Tatar Language, 2005, p. 768]. There are relatively few words in the dictionary that refer to gender in adolescence. At the same time, such lexemes as usu, usesh, usenu, usteru, usu, cognate to the words usmer, usmerlek, occupy a fairly large place. There is one thing in common between the word adolescent and words derived from the root $u s-$ : adolescents are those who have emerged from childhood, but do not fit the society of adults due to lack of certain parameters (physical, mental development, etc.), they are still developing. There is reason to believe that adolescence ends with the coming of age. The importance of this moment is reflected in the language by various lexemes. For example, the "Dictionary of Synonyms" made it possible to determine the following options: "baliq bulu (to reach adulthood) - baliqlyk, balagat, zhitlegu, yashe zhitu, buyga zhitu, zur bulu, zurayu, usep zhitkan bulu, zhitlekkanlek, zhiteshu" [Hanbikova, 1999, p. 20].

Teenagers in their teens are also referred to as yeget, kyz, tutash.

In the Tatar language, the lexeme yashlek in most cases has a positive connotation, it is viewed in connection with beauty, strength, enthusiasm, readiness for a new social role in the family and society. At the same time, there are words with the semantics of frivolity and superficial thinking characteristic of adolescents. As the study of the lexical data from the dictionary shows, the word "yash" has many possibilities in terms of derivation in the Tatar language. In the "Explanatory Dictionary of the Tatar Language" the following parts of speech are recorded: 1) nouns: yashzhilkenchak, yash-zhilbazak, yashusmer; 2) verbs: 
yashsenu, yashsetu; 3) adverbs: yashli, yashlay, yashlarcha, yashlata, yashtan [Explanatory Dictionary of the Tatar Language, 2005, p. 739].

In Azerbaijani, the lexical unit yeniyetma (teenager) is used to convey the period of youth: Yeniyetmalarin tarbiyasi (upbringing a teenager), yeniyetmolar arasında kütlavi iş (mass work among teenagers), yeniyetma oğlan (a teenage boy), yenziyetmo oslan (a teenage boy), yeniyetma qiz (a teenage girl) [https://translate.academic.ru].

The lexical unit yeniyetmalik means adolescence between childhood and youth: yeniyetmalik yaşından çıxmaq (to leave adolescence).

In Tatar poetry, it is customary to call the youth "the dawn of life" or "the spring of life".

In the Tatar and Azerbaijani languages, the period of youth is traditionally the period of falling in love, marriage, in other words, the period of acquiring new social statuses; this period is remembered as a representation of a person's new status in relation to marriage.

In the Tatar language, among the lexemes with the semantics of youth, there are words describing this time as a period of frivolity and panache.

The lexis, relating to the period of maturity, to middle-aged people, is stylistically neutral, and relatively limited in number, mainly used in addressing people (efende, khanym, grazhdanin, etc.) and in the names expressing different kinship that play the role of address.

People who have reached maturity are called zurlar (adults). This generalized word is concretized in the synonyms olkannar, olylar, olkan keshelar, abyi-apalar, agai-apalar [Hanbikova, 1999. p. 42].

The very idea of growing up is associated with the concepts of "improvement, growth": zhirkelekle, zhitlekle, zhitleksez, zhitlekteru. Linking the growing up of people with their independent lives makes it possible to include the words ir (husband), khatyn (wife), ir-at (man), khazyn-kyz (woman), kilen (daughter-in-law), kiyau (son-in-law), apa (aunt), abyi (uncle), agay (uncle, polite address to an older man), abzyi (uncle, addressing politely an older man) in this group. This linguistic phenomenon is evident in compound nouns like eget-zhilan, kyz-kyryn. For example, in the "Explanatory Dictionary of the Tatar Language" eget-zhilan is explained as "boys and teenagers" [Explanatory Dictionary of the Tatar Language, 2005, p. 156]. The lexeme kyzkyryn is listed in the dictionary as "girls of different ages" [Explanatory Dictionary of the Tatar Language, 2005, p. 130].

In the Azerbaijani language, the period of growing up is expressed by the lexical unit yetişkanlik. This word forms the following synonymous series in the Azerbaijani language: yetkinlik, bişkinlik, tacrübalilik, yetişkanlik, hazırlılıq, püxtalik, yetkinlik [Azərbaycan dilinin izahlı lüğəti, 2006, p. 744.]

The study of lexical units, related to the period of "old age", shows the following: the Tatar people from ancient times were polite and attentive to the older generation, in the family the place of grandparents was at the head of the table.

The lexeme abyi, as linguists note, has its origin in the Tatar language and comes from the extinct version of abai [Ahmetyanov, 2001, p. 8]. In the "Explanatory Dictionary of the Tatar Language" two of its meanings are recorded: "1) a male relative older than you; 2) added to the name of the older man" [Explanatory Dictionary of the Tatar Language, 2005, p. 16].

The name aga is considered to have originated "from the common Türkic root ' $a z a$, $a k ̧ a$ ', 'an adult relative, an adult, a respected person"” [Ahmetyanov, 2001, p. 9]. The same meaning is recorded in the "Explanatory Dictionary of the Tatar Language": 1) the oldest male relative, an uncle; 2) older than you, a grown man. The names aga and the namesake agai, agai-ene, againe have a dialectal variant $a k a$ [Explanatory Dictionary of the Tatar Language, 2005, p. 19].

The lexical unit that expresses relationships and has the opposite meaning to the lexemes above is ene. In the "Explanatory Dictionary of the Tatar Language" its meaning is explained as follows: "a younger male relative" [Explanatory Dictionary of the Tatar Language, 2005, p. 708].

The dictionary also contains the diminutive form of this word enekash, formed according to the model of the modal suffix ene $+-k a s h$, and enem as a form of addressing a younger man, formed according to the model ene + suffix I of the singular number $-m$. In both cases, this lexeme is used in relation to the younger person, this property retains its etymological meaning. In R. Akhmetyanov's work, the origin of this lexical unit is explained as follows "from the word ini, eni "younger brother, younger relative (brother and sister)", the same root as ana" [Akhmetyanov, 2001, p. 255].

In Tatar dialects, apai is used as a dialectal variant of the word enekesh. The word ene together with the word agai form a paired construction and form the collective noun agai-ene. Its two 
meanings are recorded in the dictionary: "1) one's brother and one's younger brother, two related men; 2) an insider" [Explanatory Dictionary of the Tatar Language, 2005, p. 20].

Separate lexical units are used for women of venerable age. For example: anakai -addressing a woman of age [Explanatory Dictionary of the Tatar Language, 2005, p. 40].

The explanatory dictionary notes that the word abystai can be used in relation to an adult woman: it is used for the purpose of respect, reverence for an adult woman [Explanatory Dictionary of the Tatar Language, 2005, p. 16].

In the 18th century, in Azerbaijan during the period of the khanate, the words xan (khan), aga or bey (efende), xanım (khanim) were used to address married women, and beyim - unmarried women.

During the Soviet period, the lexical unit yoldash (comrade) became active in the Azerbaijani language.

In the 1990s, mellim was used as a lexical unit to address men, not only in relation to teachers, but also as a form of polite address. It was used with a personal name: Mamed mellim, Musa mellim.

There were also forms of address of religious nature, some of which are still used today: meshedi is the name given to a person who has performed the Hajj to the city of Mashhad, hacı is a Muslim who has performed the Hajj to Mecca, kerbalayı is a Muslim who has performed the Hajj to the city of Kerbal, seyid is a person from the clan of the Prophet Muhammad, sheyx is the head, axund is a religious figure, molla is a mullah.

Today, in the Azerbaijani language, the most respectful address towards a man is bey; and in relation to a woman xanım is used [Azərbaycan dilinin izahlı lüğəti, 2006, p. 744].

When addressing strangers and adults they use the personal pronoun siz (you).

Like in Tatar, in the Azerbaijani language, $\mathrm{bacl}$ (aunt); gardash, dayl, emi (uncle); xala (aunt) are used in relation to unfamiliar adults [Azərbaycan dilinin izahlı lüğəti, 2006, p. 744.]

In the Azerbaijani language, an adult man is transmitted by the lexical units pir, qart, qoca, ahıl, çalbaşll.

The old age is also perceived as a period of experience, intelligence, wisdom and deterioration of physical qualities by the Tatar and Azerbaijani peoples. These phenomena do not show adults as defective, weak, with physical and mental disabilities, but first of all make it possible to describe them as experienced, able to advise, intelligent people who are the standards of wisdom.
Thus, in the Tatar and Azerbaijani pictures of the world, according to age characteristics, the following portrait of a person is formed: a child is born with joy and happiness to the family, the surrounding reality, and to the world in general. It is being expected, and, to show that it has support in this world, gifts are given to its mom and to the child.

In adolescence, a lot of attention is paid to identifying children by their gender. Girls, basically, are brought up as helpers to their mothers, keepers of the hearth in their future husbands' houses; the upbringing of boys is directed towards education and work. The interference of the younger ones in the affairs of adults is perceived with disapproval, modesty in both boys and girls is considered to be a great quality.

Adolescence is thought to be the time of gaining authority among peers, developing high moral qualities and achieving excellence. During this period, a person can indulge in a little bragging, arrogance, and this is reflected in lexical units. However, the "difficulties associated with the transition period", about which psychologists are now talking a lot, are not reflected in our vocabulary. If the lexis of youth is presented in connection with the search for a beloved one, the creation of a family, then the period of growing up is described with the words abyi, apa, agai, abzyi, khanym, efende. In the Tatar and Azerbaijani languages, old age is the period of accumulation of wisdom and intelligence.

The lexis, expressing age characteristics, is studied in connection with a person, it does not only express the difference in age, but also determines the character and internal state of mind.

Most of the words, expressing age characteristics, are derivatives formed with the suffixes -lyk/-lek.

\section{References}

Azarbaycan dilinin izahlı lüğati: I cild (2006) [Explanatory Dictionary of the Azerbaijani Language: Volume I]. Müəllif. Nəşriyyat, Şərq-Qərb. Nəşr yeri, 744 p. Bakı. Nəşr ili. (In Azerbaijani)

Bazen, L. (1986). Kontseptsiia vozrasta u drevnikh tiurkskikh narodov [The Concept of Age among the Ancient Türkic Peoples]. Zarubezhnaia tiurkologiia. Vyp. I. Drevniie tiurkskiie iazyki i literatury. Pp. 361-378. Moscow. (In Russian)

Baiazitova, F. S. (2014). Bishek tue leksikasy (etnolingvistik aspect) [A Name-Giving Holiday Vocabulary (Ethnolinguistic Aspects)]. Fonni Tatarstan, No. 1, pp. 34-39. (In Tatar) 
Baiazitova, F. S. (1992). Gотегпнең өсh tuе: tatar halyknyy gaila jolalary [Three Weddings of a Lifetime: Family Rituals of the Tatar People]. 291 p. Kazan, kit. nəshr. (In Tatar)

Dzhamirova, L. I. (2015). Strukturnosemanticheskii analiz vozrastnoi leksiki $v$ tadzhikskom iazyke: dis. ... kand. filol. nauk [Structural-Semantic Analysis of Age-related Vocabulary in the Tajik Language: Ph.D. Thesis]. 172 p. Dushanbe. (In Russian)

Hanbikova, Sh. S., Safiullina, F. S. (1999). Sinonimnar syzlege [Dictionary of Synonyms]. 255 p. Kazan, Khəter nəshr. (In Tatar)

Hashimov, R. I. (1973). K voprosu o formirovanii russkoy vozrastnoy leksiki (istoricheskoe formirovanie $i$ sovremennoe funktsionirovanie vozrastnykh naimenovanii nesovershennoletnikh detei): avtoref. dis. ... kand. filol. nauk [On the Formation of Russian AgeRelated Vocabulary (Historical Formation and Modern Functioning of Age Names for Minor Children): Ph.D. Thesis Abstract]. Moscow, 21 p. (In Russian)
Iakovleva, Ye. S. (1994). Fragmenty russkoi iazykovoi kartiny mira: Modeli prostranstva, vremeni $i$ vospriiatiia [Fragments of the Russian Language Picture of the World. Models of Space, Time and Perception]. 343 p. Moscow, Gnozis. (In Russian)

Iusupova, A. Sh. (2008). Dvuiazychnaia leksikografiia tatarskogo iazyka XIX veka [Bilingual Lexicography of the Tatar Language of the 19th Century]. 410 p. Kazan', izd-vo Kazansk. gos.un-ta. (In Russian)

Ramazanova, D. B. (2013). Tatar telenda keshega boilaneshle leksika [Human-Related Vocabulary in the Tatar Language]. 364 p. Kazan, IIALI nəshr. (In Tatar)

Tatar teleney ay̧latmaly syzlege (2005) [Explanatory Dictionary of the Tatar Language]. 848 p. Kazan, Matbugat iorty nəshr. (In Tatar)

Tatar teleneyzur dialektologist syzlege (2009) [Large Dialectological Dictionary of the Tatar Language]. 839 p. Kazan, Tatar kit. nəshr. (In Tatar)

\title{
ТАТАР ҺӘМ АЗӘРБАЙЖАН ДӨНЬЯ ТЕЛ СУРӘТЕНДӘ ЯШЬ ҮЗЕНЧӘЛЕКЛӘРЕНӘ БӘЙЛЕ ЛЕКСИК БЕРӘМЛЕКЛӘР
}

\author{
Махира Наги гызы һүсәйнова, \\ Азәрбайжан дәүләт педагогика университеты, \\ Азәрбайжан, Баку ш., Ү. Нажибәйле ур., 68 нче йорт, \\ mahire.huseynova@adpu.edu.az. \\ Фирүзә Рәмзил кызы Сибгаева, \\ Казан федераль университеты, \\ Россия, 420008, Казан ш., Кремль ур., 18 нче йорт, \\ FiruzaRS@mail.ru.
}

\begin{abstract}
Соңгы берничә елда кеше белән бәйле, аның эчке һәм рухи дөньясы, дөньяга карашы белән бәйле тел күренешләрен өйрәнү юнәлеше активлаша бара. Кешегә караган тел берәмлекләре hәрвакыт кешенең үзе белән бәйле була. Аларны бер-берсеннән аерып карау мөмкин түгел. Сүзлекнең күп өлешен кеше белән бәйле лексика, төшенчәләр, гыйбарәләр алып тора. Бу берәмлекләр арасында кешенең яшь үзенчәлекләрен белдерә торган лексик берәмлекләр дә бар. Алар кешенең физик, рухи көче, аның теге яки бу күнекмәгә ия булуы, көнкүреш һәм жәмгытьтә тоткан урыны, активлыгы белән турыдан-туры бәйләнгән була.

Бу мәкаләдә кешенең яшь үзенчәлекләрен чагылдыра торган лексика өйрәнелә, һәм ул яшь аермаларын гына билгеләп калмыйча, аның холкын, күңел халәтен дә билгеләргә ярдәм итә.
\end{abstract}

Төп төшенчәләр: яшь үзенчәлекләренә бәйле лексика, татар теле, азәрбайжан теле, дөнья тел сурәте, ижтимагый термин, яшь үзенчәлеге, чор.

Сүз чынбарлыктагы күренеш һәм әйберләрне атый һәм шул сыйфаты аша реаль тормышның системалылыгын турыдан-туры чагылдыра. Яшь үзенчәлекләрен чагылдырган лексика бик борынгы заманнарда барлыкка килгән, шуңа күрә аларның мәгънә үзенчәлекләрен, алар белән бәйле гореф-гадәтләрне өйрәнү борынгы тормыш-көнкүрешне күзалларга, халык тарихында булып үткән төрле вакыйгаларны ачыкларга мөмкинлек бирә.

Соңгы берничә дистә елда тел күренешләре кешенең фикерләве, рухи дөньясы, дөньяга карашы, дөньяны күзаллавы белән бәйләнештә өйрәнелү тенденциясе арта бара. Чынлап та, кеше һәм тел төшенчәләре бер-берсеннән аерым күзаллана алмый. һәрбер телнең иң зур 
өлешен кеше белән бәйле лексик берәмлекләр, төшенчәләр тәшкил итә. Алар арасында кешенең яшь үзенчәлекләрен чагылдыра торган лексика да бар. Бу - табигый да. Кешенең физик һәм, күпчелек очракта, рухи көче, күнекмәләре, ижтимагый тормышта катнашу дәрәжәсе аның яшь үзенчәлекләренә турыдантуры бәйләнгән була.

Татар һәм азәрбайжан телләрендә яшь үзенчәлекләрен белдерә торган лексиканы өйрәнүгә караган фәнни хезмәтләр арасында түбәндәгеләрне күрсәтергә мөмкин: А.Т. Бекмуратова [1978], Е.С. Айбазова [1981], Д.М. Шихмурзаев [1985], Х.Г. Юсупов [1959] h.б. Аерым диалектлар яки сөйләшләрдәге яшь Үзенчәлекләрен чагылдырган лексик берәмлекләр М.М. Абакарова, Н.Э. Гаджиахмедовларның [1985] туганлык атамаларын барлауга багышланган тикшерүләрендә күп урын алып тора, С.Ф. Миржанова [1973] h.б. хезмәтләрендә яшь үзенчәлекләренә хас лексика карала.

Бу юнәлештә Э.В. Севортянның этимологик сүзлекләре [1974, 1978, 1980, 1986] дә зур әһәмияткә ия. Анда борынгы һәм хәзерге төрки телләр буенча гаять зур фактик материал тупланган һәм анализланган, шул исәптән яшь үзенчәлекләрен чагылдырган лексиканың килеп чыгуы, семантик һәм функциональ үсешҮзгәрешенә караган төп гомумтеоретик мәсьәләләр дә каралган.

Яшь үзенчәлеге - кеше тормышы һәм аңының мөһим өлеше. Яшәешнең универсаль категорияләрнең берсе буларак, тормышның həp мизгеле кешедә һәрдаим кызыксыну уята. Тел белемендә вакыт проблемасы онтологик, лингвокультурологик аспектларда Е.С. Яковлева хезмәтләрендә яктыртыла [Яковлева, 1994]. Шул ук вакытта кеше һәм вакыт бәйләнеше буларак яшь үзенчәлекләрен чагылдырган лексикага карата кызыксыну да көчәеп китә. Галимнәр яшь үзенчәлеген чагылдырган лексиканы төрле аспектларда өйрәнәләр. Мондый төр лексиканы өйрәнүгә XX гасырның житмешенче елларында Р.И. Хашимов, Г.А. Путягин, В.Г. Гак Л.Т. Костина игътибар итә. Аны беренчеләрдән булып Р.И. Хашимов өйрәнә [Хашимов, 1973, б. 21].

Яшь үзенчәлекләрен чагылдырган лексика XIX гасырда төзелгән күп санлы ике телле сүзлекләрдә дә шактый урын ала.

Бу турыда Ә.Ш. Юсупованың «Двуязычная лексикография татарского языка XIX века» [2008] дигән хезмәтендә бай һәм жентекле анализ бирелгән. Автор хаклы рәвештә, әлеге сүзлекләрдәге лексиканы тикшеру татар теленең сүзлек составын тарихи аспектта өйрәнү өчен гаять әһәмиятле, дигән фикер уздыра.

Телнең сүзлек фондын тулаем, комплекслы итеп өйрәнергә омтылу галимнәрне төрле алымнар белән тикшеренүләргә этәрә, лексик фондны төрле яклап барлау юллары ачыла. Соңгы елларда Д.Б. Рамазанованың «Татар телендә кешегә бәйләнешле лексика» дип аталган зур күләмле монографиясе дөнья күрде [Рамазанова, 2013, б. 8].

Мәкаләдә фактик материалны анализлауда төрле метод һәм алымнар кулланылды. Жыелган фактик материал лингвистикада төп метод булган күзәтү һәм теркәү методы нигезендә классификацияләнә. Моннан тыш, лексик берәмлекләрне анализлауда тарихичагыштырма, тасвирлама, типологик, семантик анализ методлары, антропоцентрик анализ алымы файдаланылды.

Татар телендә яшь үзенчәлекләрен чагылдыра торган лексик берәмлекләрнең үзәгендә «яшь» сүзе тора. «Татар теленең аңлатмалы сүзлеге»ндә аның ике мәгънәсе теркәлгән: 1) кеше яки кайбер хайван гомеренең бер елы; 2) кешенең, хайваннарның, үсемлекнең яшәу чоры [Татар теленең аңлатмалы сүзлеге, 2005, б. 739].

Кешенең хронологик яшенә карап, аны төрле атамалар белән йөртәләр. Татарларда яңа туган бала бәби, сабый, нарасый һәм күкрәк баласы кебек атамалар белән йөртелә. Бәби сүзенең сүзлектә теркәлгән мәгънәсе дә - «яңа туган, имчәк баласы» [Татар теленең аңлатмалы сүзлеге, 2005, б. 101]. Сүзлектә имчәк лексемасының мөстәкыйль лексема статусында йөргәнлеге ассызыклана [Татар теленең аңлатмалы сүзлеге, 2005, б. 185].

Сабый 1) бик яшь, кечкенә (балалар турында); || күч. бик өстән генә фикер йөртүче, мәсьәләнең, хәлнең асылын аңламаучы; \| и. бәби, кечкенә бала; 2) сабыйларныкы төсле (чырай, кыяфәт h.б.); 3) сабыйлык елларына туры килә торган (чор, вакыт һ.б.) буларак аныкланыла [Татар теленең аңлатмалы сүзлеге, 2005, б. 456].

Нәни сүзенең аңлатмасы «кечкенә бала» буларак бирелә [Татар теленең аңлатмалы сүзлеге, 2005, б. 390].

Балаларга мөрәжәгать сүзе буларак, бәпкәм лексемасы да әлеге төркемгә карый. Сүзлектә бәпкәм сүзенең өченче мәгънәсе түбәндәгечә бирелә: «Картларның яшьләргә, бигрәк тә 
нәниләргә карата мөрәжәгать сүзе» [Татар теленең аңлатмалы сүзлеге, 2005, б. 103].

Татар теленең территориаль диалектларында бала мәгънәсен белдерә торган төрле сүзләр кулланылышта йөри. Мәсәлән, яңа туган, кепкечкенә баланы кайбер сөйләшләрдә пети дип атау гадәте бар. Л.Т. Мәхмүтова сүзлек текстында: пети - кечкенә дип аңлата [Татар теленең зур диалектологик сүзлеге, 2009, б. 528]. Шулай ук сүзлектә каргалы, бәрәңге сөйләшләрендә әтисе үлгәннән соң балага карата кулланыла торган атама да теркәлгән, андыйларны мирас бала дип атап йөрткәннәр [Татар теленең зур диалектологик сүзлеге, 2009, б. 479].

Бәби тапканда булышучы, киңәшче, юатучы, бала тугач та, беренче гигиена таләпләрен жиренә житкереп үтәүче хатыннарны кендек әбисе дип йөрткәннәр. Төрле жирлекләрдә атамаларның төрлечә йөртелүенә игътибар итеп, Ф. Баязитова түбәндәге лексик берәмлекләрне мисал рәвешендә китереп үтә: кендек әби, кендекәй, олан әбисе, бәбәй әбисе, түти әби, әби тәтә, әби әңкә, инәлек корткаяк, мамай, авыл әбисе һ.б. [Баязитова, 2014, б. 35]. Бала туу хөрмәтенә үткәрелгән мәжлес атамалары да төрлечә әйтелгән: бәби мае - казан арты, мишәр диалекты сөйләшләрендә; бәби туе, бәби боткасы - тау ягы сөйләшендә; бәби чәе касыйм, сергач сөйләшләрендә.

Татар телендә «балачак» дәвере шактый күп лексемалар аркылы чагылыш таба. Әлеге төркем сүзләрнең үзәген тәшкил иткән бала лексемасы нигезендә бик күп яңа сүзләр хасил була: баласылу, балалану, балалау, балага узу, бала төшерY, балачак, баласыз, бала-чага. Күренгәнчә, алар кушымчалау, нигез кушылу ысуллары белән ясалганнар. Шунысы үзенчәлекле: бала-чага жыелма исеме бала сүзе белән аның диалекталь варианты чага сүзе кушылу нәтижәсендә ясалган. Мишәр диалектының кайбер сөйләшләрендә чага сүзе бала сүзенә якын мәгънә, шул исәптән «эт, мәче, дуңгыз, куян кебек вак хайваннарның баласына карата әйтелә торган сүз» мәгънәсен белдерә [Татар теленең зур диалектологик сүзлеге, 2014, б. 723].

Азәрбайжан телендә исә bəbə, körpə, çağa лексик берәмлекләре бала, сабый мәгънәләрен бирүдә кулланылалар. Бүген азәрбайжан теленең актив лексикасыннан пассив лексикасына күчкән cunquş сүзе кайбер диалект сөйләшләрендә генә яши. Актив лексик берәмлек буларак kӧrрә лексик берәмлеге кулланылышта йөри. Ул күкрәк баласы, кечкенә бала; сабый мәгънәләрен белдерә [https://translate.academic.ru]. Körpə nəfəsi (сабый сулышы), körpəni әmizdirmək (сабыйны имезү), körpəni sakit etmək (сабыйны тынычландыру), körpəni qucağına götürmək (almaq) (баланы кулга алу), körpəni bağrına basmaq (сабыйны күкрәккә кысу), körpəni döşdən ayırmaq (сабыйны күкрәктән аеру), körpəуə ad qоymaq (сабыйга исем бирү), körpəуə Layla çalmaq (баланы йокларга салу).

Шулай ук kӧrрә сүзе яшь мәгънәсен дә белдерә. Мәсәлән, Sən hən hən çox körpəsən (шаяртырга син әле артык яшь), insanları mühakimə etmək üçün siz hələk körpəsiniz (кешеләрне хөкем итәр өчен сез әле яшь).

Өлкәннәр үзләреннән кече яшьтәгеләргә: oglum (улым), qlzım (кызым) дип тә эндәшәләр.

Бала дигәндә, татар һәм азәрбайжан халкы бишектән төшкәннән унике яшькә кадәрге яшәу чорын күзаллый. Сүзлекләрдәге лексемалар, бер яктан, баланың тәжрибәсез, самими булуын ассызыкласа (көчек, борын асты кипмәгән, маңка), икенче яктан, балаларның төп социаль роле - белем, тәжрибә туплау белән бәйләнгән булуын күрсәтәләр (укучы, шәкерт, талип). Анализ барышында балаларны гендер ягыннан да аеруның зур урын алуы күренә (кыз, малай). Ике халыкта да женес ягыннан аеру аларга гына хас булган үзгәрешләр белән бәйле. Балалыктан чыгу дәверендә бала үсмерлек чорына күчә.

Үсмерлек чоры «балалыктан яшьлеккә кадәрге вакыт», ә үсмер «12 дән 16-17 яшькә кадәр булган бала, яшүсмер» [Татар теленең аңлатмалы сүзлеге, 2005, б. 768]. Сүзлектә үсмер чакка караган зат атамалары чагыштырмача күп түгел. Аның каравы Yсмер, Yсмерлек сүзләренә тамырдаш булган $Y c Y$, Yсеш, ҮсенY, YстерY, $Y c Y$ кебек лексемалар шактый зур урын алалар. Үсмер белән үстамырыннан ясалган сүзләр арасында бер уртаклык бар: үсмерләр - балалыктан чыккан, әмма олылар социумында аерым параметрлар (физик, психик үсеш h.б.) тиң кабул ителә алмаган, әлегә үсү процессын кичерә торган чор. Үсмерлек чоры балигъ булу белән тәмамлана, дип уйларга жирлек бар. Әлеге мизгелнең әһәмияте аның халык телендә төрле лексемалар белән аталыш алып таралуында да чагылыш таба. Мәсәлән, «Синонимнар сүзлеге»нә мөрәжәгать итү түбәндәге вариантларны ачыкларга мөмкинлек бирде: «балигъ булу балигълык, баләгать, житлегү, яше житү, буйга 
житү, буй житү, зур булу, зураю, үсеп житкән булу, житлеккәнлек, житешү» [Ханбикова, 1999, б. 20].

Үсмерлек чорын кичерүче кешеләргә карата егет, кыз, туташ кебек мөрәжәгатьләр дә кулланыла.

Яшьлек лексемасы телебездә күпчелек очракта уңай коннотациягә ия. Ул матурлык, яз, көч, дәрт, гаиләдә һәм жәмгыятьтә яңа социаль рольләргә әзерлек белән бәйләнештә карала. Шул ук вакытта яшьләргә хас жилбәзәклек, төптән уйламау кебек семантикага ия булган сүзләр дә очрый. Сүзлектә тупланган лексик берәмлекләрне өйрәнү нәтижәләре күрсәткәнчә, татар телендә «яшь» сүзе сүз ясалышы ягыннан зур мөмкинлекләргә ия. «Татар теленең аңлатмалы сүзлеге»ндә алар арасында түбәндәге сүз төркемнәре теркәлгән: 1) исемнәр: яшь-жилкенчәк, яшь-жилбәзәк, яшүсмер; 2) фигыльләр: яшьсенү, яшьсетү; 3) рәвешләр: яшьли, яшьләй, яшьләрчә, яшьләтә, яшьтән [Татар теленең аңлатмалы сүзлеге, 2005, б. 739].

Азәрбайжан телендә яшьлек чорын белдерә торган yeniyetmə (яшүсмер) лексик берәмлеге кулланыла: Yeniyetmələrin tərbiyəsi (яшүсмерләрне тәрбияләү), yeniyetmələr arasında kütləvi iş (яшүсмерләр арасында массакүләм эш), yeniyetmə oğlan (малай-яшүсмер), yeniyetmə q1z (кыз-яшүсмер) [https://translate.academic.ru].

Yeniyetmalik лексик берәмлеге балачак белән яшьлек арасында була торган үсмерлек чорын белдерə: yeniyetməlik yaşından çıxmaq (яшүсмер яшеннән чыгу).

Татар шигъриятендә яшьлекне «гомер таңы» яисә «гомер язы» дип атау еш очрый.

Татар һәм азәрбайжан телләрендә яшьлек чоры традицион рәвештә яр сөю, өйләнү, кияүгә чыгу, димәк, яңа социаль статусларга ия булу чоры; кешенең өйләнү / кияүгә чыгу белән бәйле рәвештә яңа социаль роль уйный башлавы, яңа статус алуын калку гәүдәләндерү буларак та күзаллана.

Татар телендә яшьлек чоры семантикасына ия булган лексемаларда яшьлек чорын жилбәзәклек, көязлек чоры итеп сурәтли торган берәмлекләр дә очрый.

Житлегү чоры, кеше гомеренең урта яшьләрдәге чорына караган лексика стилистик яктан нейтраль, чагыштырмача азсанлы булуы белән аерылып тора һәм, нигездә, мөрәжәгать сүзләре (әфәнде, ханым, гражданин һ.б.), мөрәжәгать сүзләр вазифасын үтәүче туганлык атамаларында чагылыш таба.
Житлегү чорына житкән кешеләрне халык зурлар дип атый башлый. Гомумиләштереп әйтелгән бу сүз синонимнарда конкретлаша төшә: өлкәннәр, олылар, өлкән кешеләр, абыйапалар, агай-апалар [Ханбикова, 1999. б. 42].

Житлегү сүзе үзе «камилләшү, үсү» төшенчәләре белән бәйләнгән: жчиткелекле, жситлекле, жситлексез, ж⿻итлектерү. Шәхеснең житлегүен мөстәкыйль яши башлау белән бәйләп карау ир, хатын, ир-ат, хатын-кыз, килен, кияү, апа, абый, агай, абзый (урта яшьтәге хатын-кыз яисә ир-атка карата мөрәжәгать сүзе мәгънәсендә) кебек сүзләрне дә әлеге төркемгә кертергә мөмкинлек бирә. Егет-жсилән, кыз-кыркын кебек жыйма исемнәрдә бу ачык чагылыш таба. Мәсәлән, «Татар теленең аңлатмалы сүзлеге»ндә егетжилән «егетләр һәм яшүсмерләр» буларак аңлатыла [Татар теленең аңлатмалы сүзлеге, 2005. б. 156]. Кыз-кыркын лексемасы сүзлектә «төрле яшьтәге кызлар» дип бирелә [Татар теленең аңлатмалы сүзлеге, 2005, б. 130].

Азәрбайжан телендә житлегу чоры yetişkənlik лексик берәмлеге белән белдерелә. Әлеге сүз азәрбайжан телендә түбәндәге синонимик рәтне барлыкка китерә: yetkinlik, bişkinlik, tacrübalilik, yetişkanlik, hazırlılıq, püxtəlik, yetkinlik [Azərbaycan dilinin izahlı lüğəti, 2006, s. 744.]

«Картлык» чорына бәйле булган лексик берәмлекләрне өйрәнү шуны күрсәтә: татар халкы элек-электән өлкән буынга карата ихтирамлы, игътибарлы булуы белән аерылып торган, гаиләдә әби-бабайның урыны түрдә булган.

Абый лексемасы, лингвистика галимнәре искәртүенчә, татар теленең үзендә ясалган һәм инде югалган абай вариантыннан килә [Әхмәтьянов, 2001, б. 8]. «Татар теленең аңлатмалы сүзлеге» ндә аның ике мәгънәсе теркәлгән: «1) үзеңнән олырак ир туган; 2) яшь ягыннан Үзеңнән олы ир кеше исеменә кушып әйтелә» [Татар теленең аңлатмалы сүзлеге, 2005, б. 16].

Ага атамасы «гомумтөрки “аға, ақа", “олы туган, олы кеше, хөрмәтле кеше” тамырыннан» барлыкка килгән, дип фаразлана [Әхмәтьянов, 2001, б. 9]. Шушы ук мәгънә «Татар теленең аңлатмалы сүзлеге»ндә дә теркәлгән: 1) яшь ягыннан олы ир туган, абый; 2) үзеңнән олырак, өлкән ир кеше. Ага һәм шушы тамырдан ясалган агай, агай-эне, агайне кебек атамаларның диалекталь варианты әкә атамасы булуы ачыклана [Татар теленең аңлатмалы сүзлеге, 2005, б. 19]. 
Югарыда аталган лексемаларга яшь ягыннан капма-каршы мәгънәне белдергән туганлык атамасы - эне. «Татар теленең аңлатмалы сүзлеге»ндә аның мәгънәсе түбәндәгечә аңлатыла: «кече ир туган» [Татар теленең аңлатмалы сүзлеге, 2005, б. 708].

Сүзлектә шулай ук сүзнең иркәләп эндәшү формасы буларак, эне + -кәш модаль кушымчаcbl моделе буенча ясалган энекәш һәм үзеңнән кечерәк ир затына мөрәжәгать итү формасы буларак, эне + I зат берлек сан кушымчасы -м моделе буенча ясалган энем сүзләре теркәлгән. Ике очракта да әлеге лексема сөйләүчегә караганда кечерәк яшьтәге затка карата кулланыла, бу ягы белән этимологик мәгънәсен саклый. Р. Әхмәтьянов хезмәтендә бу лексик берәмлекнең килеп чыгышы «гом. тк. ини, эни “эне, кече туган (эне һәм сеңел)" сүзеннән, ана белән бер төптән булса кирәк» дип аңлатыла [Әхмәтьянов, 2001, б. 255].

Татар диалектларында энекәш сүзенең диалекталь варианты буларак апай атамасы да кулланыла. Эне сүзе, агай сүзе белән янәшә килеп, парлы конструкция төзү хисабына, агайэне жыйма исем ясауда да катнаша. Сүзлектә аның ике мәгънәсе теркәлгән: «1) ага һәм эне, агалы-энеле, бертуган ике ир кеше; 2) Y3 кешеләр, үзебезнең кешеләр» [Татар теленең аңлатмалы сүзлеге, 2005, б. 20].

Өлкән яшьтәге хатын-кызларга карата да аерым лексик берәмлекләр кулланыла. Мәсәлән: анакай - олы яшьтәге хатын-кызга мөрәжәгать сүзе [Татар теленең аңлатмалы сүзлеге, 2005, б. 40].

Аңлатмалы сүзлектә абыстай сүзенең өлкәнрәк хатын-кызга мөрәжәгать сүзе дип бирелгән сүзлек мәкаләсе дә бар: олы яшьтәге хатын-кызны ихтирам итү, зурлау йөзеннән исеменә кушып әйтелә [Татар теленең аңлатмалы сүзлеге, 2005, б. 16].

XVIII гасырда, Азәрбайжанда ханлыклар дәвере булганда, xan (хан), aga яки bey (әфәнде), xanım (ханым) - кияүдә булган хатын-кызларга, ә beyim - кияүгә чыкмаган хатын-кызларга мөрәжәгать итү формаларын кулланганнар.

Совет чорында азәрбайжан телендә yoldash (иптәш) лексик берәмлеге активлаша.

Узган гасырның 90 нчы елларында иратларга мөрәжәгать итү формалары арасында mellim лексик берәмлеге укытучыларга карата гына кулланылмыйча, ихтирамлы мөрәжәгать сүзе буларак та кулланылган. Ул шәхси исем белән яраштырып кулланылган: Mamed mellim, Musa mellim.
Шулай ук дини эчтәлекле эндәш сүзләр дә булган, әлеге сүзләрнең кайберләре бүгенге көндә дә кулланылышта йөри: мeshedi Мешхед шәһәренә хаж кылган кешегә бирелгән исем, hacl - Мәккәгә хаж кылган мөселман, kerbalayı - Кербал шәһәренә хаж кылган мөселман, seyid - Мөхәммәд (с.г.с.) токымы титулыннан булган кеше, sheyx - башлык, axund - дин әһеле, molla - мулла.

Хәзерге вакытта азәрбайжан телендә иратка карата кулланыла торган иң ихтирамлы мөрәжәгать сүзе - bey; ә хатын-кызга хапım сүзен кулланалар [Azərbaycan dilinin izahlı lüğəti, 2006, s. 744].

Чит, өлкән кешеләргә һәм рәсми затларга карата мәрәжәгать итү формасы буларак, siz (сез) зат алмашлыгы кулланыла.

Татар телендә кулланылган кебек үк, азәрбайжан телендә дә таныш булмаган өлкән яшьтәге кешеләргә: bacı (апа); gardash, dayı, emi (абый); xala (апа) [Azərbaycan dilinin izahlı lüğəti, 2006, s. 744.]

Азәрбайжан телендә өлкән ир-ат мәгънәсе pir, qart, qoca, ahıl, çalbaşlı лексик берәмлекләре аша белдерелә.

Картлык татар һәм азәрбайжан халкында тәжрибәлелек, акыл, зирәклек, физик яктан зәгыйфьләнә бару чоры буларак та кабул ителә. Бу күренешләр өлкәннәрне зәгыйфь, мескен, физик һәм психик яктан тайпылышлары булган шәхесләр рәвешендә түгел, ә барыннан да элек зур тормыш тәжрибәсе булган, үгет-нәсихәткә оста, акыл, зирәклек эталоны рәвешендә тасвирлауга алшарт булып килә.

Шул рәвешле, татар һәм азәрбайжан дөнья картинасында яшь үзенчәлекләренә бәйле рәвештә, мондый кеше портреты хасил була: бала гаиләгә, якын-тирәгә, гомумән, дөньяга шатлык, бәхет белән туа. Аны көтеп алалар, якты дөньяда терәге булуын белдереп, анага тәмле әйберләр, балага бүләкләр алып киләләр.

Үсмер чорда балаларны женси яктан аеруга зур игътибар бирелә. Кызлар, нигездә, әниләренә ярдәмче, булачак ирләренең йорт учагын саклаучы буларак тәрбияләнәләр, малайларның тәрбиясе эш, белем алуга юнәлтелә. Әмма кече яшьтә булып та, олылар эшенә кысылучы балаларга халык кырыс караган, тыйнаклык малайларда да, кызларда да күркәм сыйфат буларак танылган.

Үсмерлек чоры яшьтәшләр арасында абруй казану, югары әхлак сыйфатларын тәрбияләү, камилләшү вакыты буларак күзалланган. Бу чорда кешенең бераз мактанчык, тәкәбберлек 
күрсәтә алуы лексик берәмлекләрдә чагылыш тапкан, әмма хәзерге психологлар күп сөйләгән «күчеш чоры белән бәйле авырлыклар» лексикабызда чагылыш тапмый. Яшьлек лексикасы сөйгән яр табу, гаилә кору белән бәйлелектә күзалланса, житлегү чорында кеше абый, апа, агай, абзый, ханым, әфәнде кебек туганлык атамалары, мөрәжәгать сүзләр белән аталган. Татар һәм азәрбайжан телләрендә картлык акыл туплау, зирәклектә, әхлаклылыкта үрнәк күрсәтү чоры буларак гәүдәләнә.

Яшь үзенчәлекләрен чагылдырган лексика кешегә бәйле рәвештә өйрәнелә, һәм ул яшь аермасын билгеләп кенә калмый, ә аның холкын, эчке халәтен, сыйфатын да билгели.

Яшь үзенчәлекләрен белдергән сүзләрнең күп өлеше ясалма сүзләр һәм алар еш кына лык/-лек кушымчалары нигезендә ясалалар.

\section{Әдәбият}

Azərbaycan dilinin izahlı lüğəti: I cild. Müəllif. Nəşriyyat, Şərq-Qərb. Nəşr yeri, Bakı. Nəşr ili, 2006. s. 744.

Базен Л. Концепция возраста у древних тюркских народов // Зарубежная тюркология. Вып. І. Древние тюркские языки и литературы. М., 1986. С. 361-378.
Баязитова Ф.С. Бишек туе лексикасы (этнолингвистик аспект) // Фәнни Татарстан. 2014. №1. Б. 34-39.

Баязитова Ф.С. Гомернең өч туе: татар халкының гаилә йолалары. Казан: Татар. кит. нәшр., 1992. 2916.

Джамирова Л.И. Структурно-семантический анализ возрастной лексики в таджикском языке: Дис. ... канд. филол. наук. Душанбе, 2015. 172 с.

Рамазанова Д.Б. Татар телендә кешегә бәйләнешле лексика. Казан: ИЯЛИ нәшр., 2013. 364 б.

Татар теленең аңлатмалы сүзлеге. Казан: Матбугат йорты нәшр., 2005. 848 б.

Татар теленең зур диалектологик сүзлеге. Казан: Татар. кит. нәшр., 2009. 839 б.

Ханбикова Ш. С., Сафиуллина Ф. С. Синонимнар сүзлеге. Казан: Хәтер нәшр., 1999. 255 б.

Хашимов Р.И. К вопросу о формировании русской возрастной лексики (историческое формирование и современное функционирование возрастных наименований несовершеннолетних детей): автореф. дис. ... канд. филол. наук. М., 1973. $21 \mathrm{c}$

Юсупова А.Ш. Двуязычная лексикография татарского языка XIX века. Казань: Изд-во Казанск. гос. ун-та, 2008. $410 \mathrm{c}$.

Яковлева Е. С. Фрагменты русской языковой картины мира: Модели пространства, времени и восприятия. М.: Гнозис, 1994. 343 с.

\title{
ЛЕКСИЧЕСКИЕ ЕДИНИЦЫ, ОТРАЖАЮЩИЕ ВОЗРАСТНЫЕ ОСОБЕННОСТИ В ЯЗЫКОВОЙ КАРТИНЕ МИРА ТАТАРСКОГО И АЗЕРБАЙДЖАНСКОГО НАРОДОВ
}

\author{
Махира Наги гызы Гусейнова, \\ Азербайджанский государственный педагогический университет, \\ Азербайджан, г. Баку, ул. Ү. Назибайлы, д. 68, \\ mahire.huseynova@adpu.edu.az. \\ Фируза Рамзеловна Сибгаева, \\ Казанский федеральный университет, \\ Россия, 420008, г. Казань, ул. Кремлевская, д. 18, \\ FiruzaRS@mail.ru.
}

\begin{abstract}
В последнее время языковые явления все чаще рассматриваются во взаимосвязи с мышлением, духовным миром, мировоззрением человека. Большую часть каждого языка составляют лексические единицы, понятия, связанные с человеком. Среди них есть лексика, отражающая возрастные особенности человека. Физическая и в большинстве случаев душевная сила человека, его навыки, степень участия в общественной жизни напрямую связаны с его возрастными особенностями. В статье представлена лексика, отражающая особенности возрастных групп: она определяет не только возрастные различия, но и характер, внутреннее состояние человека.
\end{abstract}

Ключевые слова: лексика отражающая возрастные особенности, татарский язык, азербайджанский язык, языковая картина мира, социальный термин, возрастная особенность, эпоха. 